\title{
DIREITOS CIVIS E DIREITOS HUMANOS uma tradição judiciária pré-republicana?
}

\author{
Roberto Kant de Lima
}

\begin{abstract}
Resumo: O tema deste artigo está centrado na justiça criminal no Brasil, buscando demonstrar que as relações entre modelos repressivos de controle social, formas inquisitoriais de produção da verdade jurídica e desigualdade jurídica formam um todo coerente em nossa justiça criminal, embora contrário à ordem republicana explícita do Estado brasileiro contemporâneo.

Palavras-chave: sistema judicial criminal; Direitos Civis e Direitos Humanos.
\end{abstract}

\begin{abstract}
The theme of this article is criminal justice in Brazil. It attempts to demonstrate that the relationships between the repressive models of social control, inquisitional methods of arriving at judicial truth and judicial inequality all come together in the Brazilian criminal justice system. These features run contrary to the notion of the republican order espoused as the guiding principle for the contemporary Brazilian nation-state. Key words: criminal justice system; civil rights and human rights.
\end{abstract}

$\mathrm{E}$ ste artigo discute alguns aspectos do sistema de justiça criminal no Brasil, relacionando-os com as estruturas jurídico-políticas de sistemas republicanos. Os dados analisados foram coletados em entrevistas e debates realizados nos últimos cinco anos, a respeito do tema, com operadores do sistema de justiça criminal, advogados e alunos de pós-graduação em direito e em segurança pública. São também analisados textos que se referem à questão da importância dos direitos civis para a ordem republicana e para a garantia da igualdade jurídica, em particular. É esta igualdade, aliás, que torna possível a compreensão contemporânea dos direitos humanos, vistos como capazes de prover tratamento igual aos diferentes, universalizando a aplicação da lei às distintas identidades que se especificam no espaço público. Como conclusão, quer-se demonstrar que as relações entre modelos repressivos de controle social, formas inquisitoriais de produção da verdade jurídica e desigualdade jurídica formam um todo coerente em um sistema de justiça criminal, embora, aparentemente, contrário às aspirações explícitas da ordem republicana constituintes do Estado brasileiro contemporâneo.
Desta forma, torna-se inicialmente relevante explicitar alguns argumentos clássicos sobre a questão da cidadania, para contrastá-los com as instituições judiciais e com as práticas judiciárias de nossa sociedade. Com este propósito, tomaremos como exemplo um autor consagrado (Bourdieu, 1974). Segundo Marshall, assim se estabelecem as relações entre a cidadania e os direitos civis: “(...) pretendo dividir o conceito de cidadania em três partes. (...) Chamarei estas três partes, ou elementos, de civil, política e social. O elemento civil é composto dos direitos necessários à liberdade individual - liberdade de ir e vir, liberdade de imprensa, pensamento e fé, o direito à propriedade e de concluir contratos válidos e o direito à justiça. Este último difere dos outros porque é o direito de defender e afirmar todos os direitos em termos de igualdade com os outros e pelo devido encaminhamento processual. ${ }^{1}$ Isto nos mostra que as instituições mais intimamente associadas com os direitos civis são os tribunais de justiça. Por elemento político se deve entender o direito de participar no exercício do poder político, como um membro de um organismo investido da autoridade política ou como um eleitor dos membros de tal organismo. As 
instituições correspondentes são o parlamento e conselhos do Governo local. O elemento social se refere a tudo que vai desde o direito a um mínimo de bem-estar econômico e segurança ao direito de participar, por completo, na herança social e levar a vida de um ser civilizado de acordo com os padrões que prevalecem na sociedade. As instituições mais intimamente ligadas com ele são o sistema educacional e os serviços sociais" (Marshall, 1967:63-64, grifos meus).

Por outro lado, ainda segundo esta concepção clássica, o conceito e o exercício da cidadania estão vinculados ao âmbito do estado nacional e à proteção dos direitos individuais: "(a evolução da cidadania) envolveu um processo duplo, de fusão e separação. A fusão foi geográfica e a separação, funcional. O primeiro passo importante data do século XII quando a justiça real foi estabelecida com força efetiva para definir e defender os direitos civis do indivíduo - tais como o eram então - com base não em costumes locais, mas no direito consuetudinário do país. Como instituições, os tribunais eram nacionais, mas especializados" (Marshall, 1967:64-65).

Então, afigura-se claramente a idéia de que esse tipo de direito e os tribunais são instituídos para a proteção dos indivíduos - antes súditos, depois cidadãos da República. Há diferenças, entretanto, do ponto de vista dos fundamentos da desigualdade nos dois contextos. Pois, para Marshall, se no Antigo Regime a desigualdade está fundamentada moral e juridicamente no status, afirmandose jurídica e politicamente o modelo da pirâmide de que falaremos mais tarde, a sociedade republicana, em que se garantiu a igualdade jurídica aos cidadãos, vai justificar a desigualdade pelas diferenças de performance entre os cidadãos no mercado. Assim, é a igualdade jurídica diante da lei e dos tribunais, que vai fornecer a justificativa moral da desigualdade econômica, política e social na sociedade cujo modelo jurídico-político pode ser representado por um paralelepípedo: a idéia de igualdade diante da lei e dos tribunais permite a desigualdade de classes nas esferas econômica, política e social, inerente ao mercado.

"Não obstante, a verdade é que a cidadania, mesmo em suas formas iniciais, constituiu um princípio de igualdade, e que, durante aquele período, era uma instituição em desenvolvimento. Começando do ponto no qual todos os homens eram livres, em teoria, capazes de gozar de direitos, a cidadania se desenvolveu pelo enriquecimento do conjunto de direitos de que eram capazes de gozar. Mas esses direitos não estavam em conflito com as desigualdades da sociedade capitalista; eram, ao contrário, neces- sários para a manutenção daquela determinada forma de desigualdade. A explicação reside no fato de que a cidadania, nesta fase, se compunha de direitos civis. E os direitos civis eram indispensáveis a uma economia de mercado competitivo. Davam a cada homem, como parte de seu status individual, o poder de participar, como uma unidade independente, na concorrência econômica, e tornaram possivel negar-lhes a proteção social com base na suposição de que o homem estava capacitado a proteger a si mesmo" (Marshall, 1967:79; grifo meu).

Ainda segundo este autor, o esquema jurídico-político que fazia parte do ideário republicano não permitia interferência no estabelecimento das condições de participação no mercado, à exceção de uma: aquela que garantia o direito dos cidadãos adultos à educação fundamental, exatamente para que pudessem estar qualificados minimamente para exercitar suas opções no mercado (Marshall, 1967:73-74).

Entretanto, esse movimento geral, já definido por Maine como um movimento do status para o contrato, requer qualificação: "Mas o elemento contratual no feudalismo coexistiu com um sistema de classes baseado em status, e à medida que o contrato se transformava em costume, contribuiu para perpetuar o status de classe. O costume reteve a forma de empreendimentos mútuos, mas não a realidade de um acordo livre. $\mathrm{O}$ contrato moderno não nasceu do contrato feudal; assinala um novo desenvolvimento a cujo progresso o feudalismo foi um obstáculo que teve que ser afastado. Pois o contrato moderno é essencialmente um acordo entre homens que são livres e iguais em status, embora não necessariamente em poder. O status não foi eliminado do sistema social. O status diferencial, associado com classe, função e família, foi substituído pelo único status uniforme de cidadania, que ofereceu o fundamento da igualdade sobre a qual a estrutura da desigualdade foi edificada." (Marshall, 1967:79-80, grifos meus).

Ora, no Brasil, a literatura jurídica é praticamente omissa quanto à questão da cidadania, a não ser quando a vincula a temas formais como, por exemplo, "liberdades públicas", ou a proclama ungida por álibis ${ }^{2}$ versados em simbologia de expressão retórica, desprovida de eficácia real para os menos favorecidos socialmente (Neves, 1994). $\mathrm{O}$ tratamento concedido à cidadania muitas vezes é tão amplo que não se consegue identificar a plena jurisdição dos direitos protetivos que a integram. Outras vezes, é limitada a princípios dogmático-formais, tão abstratos que mais justificam sua aparência simbólica do que sua vigência, o que reforça aspectos meramente retóricos em que 
fica escondida. Muito comumente ela é entendida apenas como a titularidade de direitos políticos, ou seja, como o direito de votar e de ser votado, com plena exclusão de outros direitos a ela agregados nos Estados democráticos da atualidade.

Tal situação incentiva a disposição generalizada de que no Brasil do século XXI ainda é fundamental lutar para que se obtenha a plena cidadania, a começar pelo princípio que no século XVIII fundamentou o direito civil: a igualdade de todos perante a lei e, principalmente, perante os tribunais (Marshall, 1967; Carvalho, 2001). É a desigualdade um princípio organizador oriundo da sociedade tradicional brasileira, dos tempos coloniais que, entranhada no tecido social, contamina as relações nas instituições sociais, sendo o sistema judicial criminal apenas uma das suas dimensões institucionais, ora destacadas aqui.

Os ideais de qualquer princípio de igualdade socialmente justa ficam assim debilitados na cultura jurídica internalizada e expressa na prática de profissionais do direito. A situação paradoxal de vivermos em uma sociedade onde o mercado produz constantes desigualdades econômicas, que são ameaçadoras do princípio basilar da igualdade de todos perante a lei, não lhes causa inquietações, porque tal situação é percebida como "natural", motivo pelo qual absorvem esse paradoxo, como se vê no processo penal, onde privilégios estão a desigualar o tratamento concedido a autores e co-autores dos mesmos delitos tipificados no Código Penal.

Conseqüentemente, na ausência de demarcação definida e estruturada em torno de eixos explícitos de legitimação da desigualdade, cabe a todos - mas, principalmente, às instituições encarregadas de administrar conflitos no espaço público - em cada caso, aplicar particularizadamente as regras disponíveis - sempre gerais, nunca locais - de acordo com o status de cada um, sob pena de se estar cometendo injustiça irreparável ao não se adequar à desigualdade social imposta e implicitamente reconhecida. Desigualdade esta inconcebível juridicamente em qualquer República constitucional, mas cuja existência, nesse contexto de ambigüidade em que nossa sociedade se move, goza de confortável invisibilidade. Eis porque a legislação processual penal admite tratamento diferenciado a pessoas que são acusadas de cometer infrações, não em função das infrações, mas em função da "qualidade" dessas pessoas, consagrando, inclusive, o acesso à instrução superior completa como um desses elementos de distinção. ${ }^{3}$
Por outro lado, a presença de métodos oficialmente sigilosos de produção da verdade - como no caso do inquérito policial -, próprios de sociedades de desiguais, que querem circunscrever os efeitos da explicitação dos conflitos aos limites de uma estrutura que se representa como fixa e imutável, confirmam a naturalização da desigualdade própria de nossa consciência cultural: as pessoas são consideradas naturalmente desiguais (Mendes de Almeida Jr., 1920:v.1:250-251). A função compensatória do Estado, portanto, é vista como uma literal compensação da desigualdade na administração dos conflitos em público e não uma promoção da igualdade para que as partes administrem seus conflitos em público.

A harmônica conciliação de princípios tão paradoxais não é de fazer estranheza ao sistema, baseado na dogmática jurídica e na hierarquia das normas, que propõe resolver o problema validando automaticamente aquelas situadas nos níveis mais altos da hierarquia. Assim, no topo da hierarquia de normas estão os princípios constitucionais. Estes, aparentemente, são assemelhados àqueles do due process of law dos EUA: asseguram a presunção da inocência, o direito à defesa - chamado, no direito brasileiro, de princípio do contraditório - conferindo, entretanto, um outro direito, denominado de ampla defesa, pelo qual os acusados podem e devem usar todos os recursos possíveis em sua defesa. Ora, este sistema traz em si algumas contradições. A primeira é que não é um due process of $l a w$ - expressão equivocadamente traduzida em português de forma demasiado livre como "devido processo legal" - pois esta instituição jurídico-política dos EUA é uma opção do acusado, a quem é devido - due - pelo Estado um determinado procedimento judicial, em condições estipuladas pelas quinta e sexta emendas constitucionais. Estas incluem, entre outros, o direito a um speedy trialum julgamento rápido, o que não existe em nosso sistema de processo e de julgamentos obrigatórios e de temporalidade própria. Outra característica é que, não havendo no processo nem exclusionary rules (regras de exclusão das evidências levadas a juízo), nem hierarquia de provas, que separem os fatos provados daqueles que não o foram, dentro de um processo probatório-evidence, fact, proof - tudo, literalmente, pode ser alegado em defesa, ou em acusação, o que produz uma parafernália de meros indícios - que, estranhamente, incluem também laudos periciais, como os de exames de corpo de delito, por exemplo - tanto mais ampla quanto mais abundantes forem os recursos do acusado e dos acusadores. Finalmente, ao assegurar, constitucionalmente, o direito do acusado não se 
auto-incriminar (direito ao silêncio), no Brasil não se criminaliza, como no direito anglo-americano, a mentira dita pelo réu em sua defesa, o que implica não haver a possibilidade de condenação por perjury, mas somente por falsidade de declaração por testemunha.

Abaixo da Constituição, tem-se o Código de Processo Penal, que regula três formas de produção da verdade: a policial, a judicial e a do Tribunal do Júri. Tais formas encontram-se hierarquizadas no Código da seguinte maneira:

- o inquérito policial, onde o procedimento da polícia judiciária é, oficialmente, "administrativo", não judicial e, por isso, inquisitorial, não se regendo pelo princípio do contraditório;

- o processo judicial, aplicado à maioria dos crimes e que se inicia, obrigatoriamente, quando há indícios suficientes de que um delito grave foi cometido e que sua autoria é presumida, com a denúncia feita pela promotoria dando oportunidade à defesa, pois se regula pelo princípio do contraditório, até a sentença do juiz, que exprime seu convencimento justificado pelo exame do conteúdo dos autos;

- o julgamento pelo Tribunal do Júri, processo que se aplica apenas aos crimes intencionais contra a vida humana e se inicia por uma sentença judicial proferida por um juiz (pronúncia), após a realização da produção de informações, indícios e provas, durante o inquérito policial e a instrução judicial, comum a todos os processos judiciais criminais. Neste caso, após interrogar novamente o réu, o juiz relata aos jurados, oralmente, os procedimentos anteriores, podendo defesa e acusação apresentar testemunhas para serem ouvidas. Este processo é também regido pelo contraditório e pela ampla defesa, em processo que exige a presença do réu, inclui um prolongado debate oral e que termina pelo veredicto dos jurados.

A exposição de motivos que introduz o texto do Código de Processo Penal explicita ser objetivo do processo judicial criminal a descoberta da "verdade real", ou material, por oposição à "verdade formal" do processo civil, ou seja, o que é levado ao juiz por iniciativa das partes. Por isso, os juízes podem e devem tomar a iniciativa de trazer aos autos tudo o que pensarem interessar ao processo, ex-officio, para formar o seu "livre convencimento" examinando a "prova dos autos". Assim, todos os elementos que se encontram registrados, por escrito, nos volumes que formam os processos judiciais, incluindo os inquéritos policiais, podem ganhar o mesmo "estatuto de verdade" para a sentença final, e o juiz pode, inclusive, discordar de fatos considerados incontroversos pela acusação e pela defesa:

"O princípio da verdade real, que foi o mito de um processo penal voltado para a liberdade absoluta do juiz e para a utilização de poderes ilimitados na busca da prova, significa hoje simplesmente a tendência a uma certeza próxima da verdade judicial: uma verdade subtraída à exclusiva influência das partes pelos poderes instrutórios do juiz e uma verdade ética, constitucional e processualmente válida. Isso para os dois tipos de processo, penal e não-penal. E ainda, agora exclusivamente para o processo penal tradicional, uma verdade a ser pesquisada mesmo quando os fatos forem incontroversos" (Grinover, 1999:78-79, grifo meu).

Como se vê, a ênfase está depositada no interesse público - aqui compreendido como aquele definido pelos funcionários do Estado - servindo o processo para incrementálo, acima dos interesses individuais, ou mesmo coletivos.

A esses procedimentos juntam-se outros, instituídos pela Lei $n^{\circ}$ 9.099/95, que criou os Juizados Especiais Criminais. Essa lei contempla os casos em que a pena inicialmente prevista é de no máximo um ano - agora, de dois anos - para contravenções ou crimes de pequeno potencial ofensivo. Em trabalho recente, divulgam-se dados de pesquisa qualitativa onde observa-se elevado número de renúncias, estimuladas pelos conciliadores, o que parece confirmar a tradição da conciliação, que opera no sentido de abafar os conflitos, não de solucioná-los (Kant de Lima et al., 2001).

\section{O INQUÉRITO POLICIAL}

Na expressão exemplar de um delegado de polícia, o inquérito policial é "um procedimento do Estado contra tudo e contra todos para apurar a verdade dos fatos". Assim, o inquérito policial é um procedimento no qual quem detém a iniciativa é um Estado imaginário, todo poderoso, onipresente e onisciente, sempre em sua busca incansável da verdade, representado pela autoridade policial, que, embora sendo um funcionário do Executivo, tem uma delegação do Judiciário e a ele está subordinado quando da realização de investigações.

O procedimento judiciário policial, portanto, pode ser inquisitorial, conduzido em segredo, sem contraditório, porque ainda não há acusação formal. Entretanto, embora neste nível não seja legalmente permitida a negociação da culpa, ou da verdade, é lógico que a polícia barganha, negocia, oficiosa e/ou à margem da lei, em troca de al- 
gum tipo de vantagem, tanto o que investiga como aquilo que os escrivães policiais registram nos "autos" do inquérito policial, conforme bem expressa a categoria específica "armação do processo", vigente no cotidiano da esfera policial (Kant de Lima, 1989; 1995).

Apesar de consideradas como "desvios de conduta", atribuídos a funcionários inescrupulosos, as "armações do processo" estão institucionalizadas nas práticas policiais. Em pesquisa de campo realizada, identificaram-se certas recorrências que apontam para a consistência de tais procedimentos como modalidade de produção de verdade de eficácia comprovada. Igualmente, a regulação da tortura de acordo com a gravidade da denúncia ou queixa e conforme a posição social dos envolvidos; a permissão da participação dos advogados nos inquéritos, também de acordo com as diferentes posições que estes especialistas ocupam nos quadros profissionais; o registro - ou não das ocorrências levadas ao conhecimento da polícia; a qualificação e tipificação - ou não - das infrações e crimes registrados e a abertura de investigações preliminares, que levam, ou não, à abertura do inquérito policial, são algumas das práticas recorrentes no subsistema policial. Todas, caracterizam práticas policiais movidas por interesses particularistas e, sem dúvida, estão institucionalizadas. Confirmando a tradição inquisitorial que o define juridicamente, o inquérito policial tramita em um cartório policial, alocado às delegacias de polícia civil, ou judiciária, onde os depoimentos e confissões são registrados por escrito nos autos do inquérito, ficando, posteriormente, entranhados nos autos do processo judicial, pois não há interrupção da numeração seqüencial de suas páginas. Portanto, essas declarações podem servir para o "livre convencimento" do juiz (Kant de Lima, 1989; 1995).

Depois de registradas tais práticas no trabalho de campo, pesquisas históricas complementares mostraram que os procedimentos observados eram muito semelhantes aos da "inquirição-devassa" do direito português ou da "inquisitio" do direito canônico: procedimentos sigilosos, que preliminarmente investigam, sem acusar, visando obter informações sobre perturbações da ordem denunciadas pública ou anonimamente. No procedimento inquisitorial, se o crime é leve e o acusado confessa, é apenas repreendido; se o acusado não confessa, ou se o crime é grave, o acusado é "indiciado" e o processo é encaminhado à justiça criminal.

A tradição jurídica brasileira justificava esses procedimentos como próprios de sociedades onde a desigualdade substantiva entre as partes era explícita, pois não era desejável manchar a reputação de homens de honra que podiam ser injustamente acusados, nem se desejava expor os despossuídos à ira de poderosos acusadores. O Estado, então, compensava essa desigualdade, assumindo a iniciativa da descoberta da verdade e avaliando a oportunidade de tornar a denúncia pública (Mendes de Almeida Jr., 1920) . Aqui, é evidente a produção de um ethos de suspeição sistemática motivado pelo desejo de evitar ou abafar a explicitação de conflitos, ou de punir aqueles que neles se envolvem, prejudicando a harmonia de uma sociedade de desiguais complementares, onde cada um tem o seu lugar.

Para mais uma vez demonstrar a força desta tradição inquisitorial, note-se que ela permanece vigente juridicamente, mesmo depois da Constituição de 1988, que estipulou que todos os processos administrativos ou judiciais deveriam incorporar o princípio do contraditório e da ampla defesa (art. 5, LV). No caso do inquérito policial, que permanecia inquisitorial por ser um mero processo administrativo, reafirmou-se seu caráter inquisitorial, enfatizando-se seu caráter de procedimento, e não de processo propriamente dito (Silva Jardim, 2001:27;41-47). Com esta argumentação jurídica, é possível mantê-lo inquisitorial, em um sistema constitucional acusatorial.

\section{O PROCESSO JUDICIAL}

Já vimos que o processo judicial se inicia pela denúncia do promotor - uma acusação pública que gera defesa - seguindo-se o interrogatório do juiz singular ao acusado, agora "réu". Neste interrogatório, em geral na primeira vez em que tanto o juiz quanto o promotor - e, muitas vezes, o defensor público - irão se comunicar com o réu em pessoa, defesa e acusação não participam, ou participam apenas como assistentes. Trata-se de procedimento oficialmente denominado de inquisitorial, que se auto-justifica como sendo em defesa do réu, cuja confissão atenua sua pena e no qual, por isso, o juiz deve advertir preliminarmente o acusado de que "seu silêncio poderá resultar em prejuízo de sua própria defesa”, teoria e prática que parecem colocar-se, como já se disse, em contradição com a presunção da inocência decorrente do silêncio do réu e do direito de não se incriminar.

Em compensação, se o silêncio pode vir em prejuízo da própria defesa - como diz o ditado, "quem cala, consente" - o réu pode mentir livremente, pois apenas as pessoas sinceramente arrependidas confessam a verdade. $\mathrm{O}$ crime de "falso testemunho", diferentemente do crime de 
perjury, só pode ser alegado contra as testemunhas. Seguindo ainda a tradição inquisitorial, a confissão do réu é considerada atenuante da pena, pois revela arrependimento - afinal, já é uma penitência - e desejo de reintegrar-se aos valores que sua ação transgrediu.

A seguir, "reperguntam-se" todas as testemunhas que já depuseram na polícia, com a assistência oficial e legal da defesa e da acusação. A assistência advocatícia, obviamente, varia de acordo com as posses do acusado e reflete no comparecimento qualificado - ou na ausência dele das testemunhas do processo. Por várias circunstâncias obstaculizantes ao comparecimento de testemunhas (mudanças de residência e/ou de status social e civil, dificuldade de locomoção, doenças, mortes, etc.), os réus mais pobres nem sempre conseguem trazer suas testemunhas ao tribunal. Em geral, são as pessoas de melhor condição econômica ou, pelo menos, os réus que não estão presos, que conseguem trazer suas testemunhas, assim como outras novas, para depor. Esta, entre outras circunstâncias, reafirma a presença da desigualdade social no processo judicial penal, também presente nas práticas processuais estrangeiras.

Durante o processo judicial, o réu pode permanecer preso ou em liberdade. Nos EUA, a fiança é a forma de soltar os réus e, como lá a cultura judicial é igualitária, tem sido objeto de crítica, identificando-se nela forte discriminação econômica, pois os mais pobres, permanecendo presos, têm sua defesa prejudicada, não só em função de seu pior estado psicológico, como também por não poder produzir provas em seu favor. Já no Brasil, se as fianças não são caras, essa desigualdade inscreve-se nos autos do inquérito policial - em que se registram as investigações contra os mais pobres, feitas sem advogado ou contra os mais ricos, "armadas" com o consentimento da polícia (Kant de Lima, 1989; 1995).

Além disso, importantes dispositivos legais prescrevem tratamento jurídico desigual aos acusados, no Brasil. Entre eles, a já referida "prisão especial", que assegura condições privilegiadas na prisão, concedidas a certas categorias de pessoas - como, por exemplo, aquelas portadoras de instrução superior -, que vão desde a permanência em separado dos chamados "presos comuns", em acomodações especialmente destinadas a assegurar este privilégio, até a "prisão domiciliar", cumprida na residência do acusado. Outro dispositivo é a "competência por prerrogativa de função", válida, por exemplo, para autoridades governamentais, que retira os acusados do âmbito do julgamento preconizado para os cidadãos "comuns", pelo juiz singular ou pelo júri, enviando-os para julgamento por órgãos judiciais colegiados de instâncias superiores, como os Tribunais de Justiça e os Tribunais Superiores de terceira instância, ou o Supremo Tribunal Federal. Favorecem ainda alguns acusados as chamadas imunidades parlamentares, que impunham licenças especiais dos Legislativos para processar seus membros. Essas últimas prerrogativas e imunidades eram, até há pouco tempo, válidas em qualquer circunstância, mesmo no caso de terem os acusados cometido infrações comuns anteriores ao mandato, sem relação alguma com suas atividades profissionais, como se a prerrogativa não fosse da função, mas da pessoa. Mesmo hoje, uma vez eleito, o político torna-se ungido por tais privilégios que o transformam em um "cidadão acima de qualquer suspeita", imune aos efeitos do Código Penal, aplicado aos cidadãos comuns, e só pode ser processado com a licença de seus pares, diferentemente, por exemplo, dos EUA, onde o Presidente da República Bill Clinton foi recentemente processado por um juiz comum.

Trata-se, assim, de um sistema judicial criminal que não é aplicado de forma igual a todos os cidadãos, mas que assegura privilégios, desigualdades consagradas na própria legislação penal e, como vimos, presentes nas práticas que a atualizam, como se verifica em sociedades patrimoniais estamentais (Weber, 1999:311-323; Faoro, 1958).

Finalmente, o juiz decide, de acordo com seu "livre convencimento" e fundado no conteúdo dos autos, que trazem entranhados os registros do inquérito policial contendo os depoimentos e confissões obtidos na polícia sem a presença oficial da defesa. Os procedimentos privilegiam a escrita, a interpretação e a implicitude. É interessante notar que nesse contexto de formulação de "certezas jurídicas", como aponta Malatesta (1911), tenta-se minimizar aquilo que poderia assegurar ao juiz e ao público o absoluto acerto de sua "sentença": a confissão. ${ }^{4}$

Nos casos dos crimes intencionais contra a vida humana, no entanto, o juiz singular não dá a palavra final. Nestes casos, formula uma sentença que "pronuncia" ou "impronuncia" o réu. Quando a sentença pronuncia o acusado, seu nome é inscrito no "rol dos culpados", registro do qual só sairá se absolvido no processo. Inicia-se, então, o julgamento pelo Tribunal do Júri.

\section{O JULGAMENTO PELO TRIBUNAL DO JÚRI}

Embora a literatura jurídica brasileira usualmente registre equivalências entre o procedimento judicial do Tri- 
bunal do Júri brasileiro e o da tradição anglo-americana, existem diferenças abissais entre ambos. Para começar, o nosso julgamento por júri não é uma opção do acusado, como ocorre no trial by jury, aplicado apenas aos que se declaram não culpados. Além disso, aqui esse julgamento é a culminância de vários procedimentos em que o acusado foi progressiva e sistematicamente indiciado na polícia e sucessivamente denunciado e indiciado no processo judicial, decidindo-se, finalmente, "pronunciá-lo" e inscrever seu nome no "rol dos culpados". A presunção oficiosa, portanto, é de culpa, não de inocência, o oposto do que ocorre no trial by jury americano. Note-se, também, que nos EUA o due process of law é um procedimento constitucional universalmente disponível aos cidadãos, um direito público subjetivo, para ser aplicado de acordo com leis locais, que devem ser igualmente aplicadas a todos os do lugar. O princípio da universalidade depende, portanto, da definição do universo e do espaço público, coletivo, sempre limitado, ao qual se aplica, em todos casos, o procedimento judicial que é devido pelo Estado. No caso brasileiro, o Tribunal do Júri não constitui um direito subjetivo, mas sim uma instituição judiciária obrigatória apenas para crimes intencionais contra a vida humana.

No trial by jury o juiz é o árbitro das regras de admissão de provas ou evidências que se apresentam, todas, durante o julgamento. Há uma gradação para a transformação das evidências - os dados trazidos pelas partes e admitidos em juízo - em fatos - quando são consensualmente reconhecidos como tal pelas partes envolvidas - e, finalmente, em provas - quando reconhecidas pelo juiz e pelos jurados como tal. No Brasil, ao contrário, o juiz, de um lado, é obrigado a procurar, por sua iniciativa, a "verdade real"; e, de outro, encontra-se compelido, pelo princípio da "ampla defesa", à aceitabilidade de todos os indícios trazidos pelas partes ao processo. O juiz lê os autos e os relata para os jurados, cujo conhecimento sobre os fatos, portanto, é de segunda ou terceira mão. Também diferem os procedimentos na tomada de depoimentos de testemunhas perante o júri. Nos EUA são feitas questions durante a examination e cross-examination do acusado - que consentiu em depor - e das testemunhas, que não podem ser "interrogadas" - quer dizer, não podem ser perguntadas pelo que se supõe que elas sabem, ou deviam saber - nem podem ter suas respostas induzidas. No Brasil, ao contrário, há um interrogatório obrigatório do réu, baseado no que foi apurado durante o inquérito policial e a instrução judicial, e não há regras para a tomada de depoimento de testemunhas.
Os árbitros - jurors - nos EUA são doze pessoas cuidadosamente selecionadas de comum acordo entre defesa e acusação, apenas para aquele julgamento, dentre listas amplas de todos os eleitores.

No Brasil, são sorteados de uma lista anual preparada de antemão pelo juiz, composta de pessoas de sua confiança ou a ele indicadas por pessoas ou instituições fidedignas, entre os quais se sorteiam vinte e um por mês e, destes, sete para cada julgamento. Defesa e acusação têm direito, cada uma, a apenas três recusas. O julgamento realiza-se em uma sala especialmente preparada para acomodar uma platéia, diante da qual está o juiz, tendo suspenso na parede, geralmente atrás de si, um tradicional crucifixo católico, simbolizando a "humanização" da justiça, sacralizada na fé cristã católica, embora a Constituição brasileira proclame a liberdade de crença religiosa para todos os cidadãos e a religião católica tenha deixado de ser a religião oficial do Estado brasileiro em 1889. O promotor fica ao lado do juiz, de frente para a platéia, e um escrivão senta-se do outro lado do juiz. Em duas filas, junto a uma das paredes laterais, estão sentados os jurados, vestidos com uma meia beca, à moda dos serventuários da justiça. Na parede oposta, de frente para os jurados, senta-se o advogado, acima do réu, ficando este acomodado, também diante dos jurados, no chamado "banco dos réus". Não é raro que promotor e jurados ocupem o mesmo lado da sala, à direita do juiz, como nas instalações do Primeiro Tribunal do Júri do Rio de Janeiro.

Embora possa apresentar variantes, dependendo das orientações particulares de cada Presidente do Tribunal do Júri e da época em que o prédio foi construído, esta disposição inquisitorial do espaço no Tribunal do Júri contrasta fortemente com disposição adversarial do trial by jury dos EUA, onde o acusado e sua defesa sentam-se lado a lado à acusação, de frente para o juiz e de costas para a platéia, tendo a um de seus lados os jurados, sentados na jury box. A igualdade simbólica entre as partes é representada no critério de ocupação do espaço, ficando a promotoria como uma parte igual às outras, o que reforça a presunção ideológica de inocência, só passível de alteração por uma reasonable doubt (dúvida razoável), reconhecida pelos jurados. ${ }^{5}$

No Brasil, o julgamento inicia-se, após o sorteio e o compromisso dos jurados, por novo interrogatório do acusado, feito pelo juiz. Após este procedimento novas testemunhas podem ser ouvidas, o que raramente ocorre, a não ser em julgamentos muito especiais. 
A parte mais importante do julgamento, portanto, é um debate, em que acusação e defesa se defrontam, com direito a duas horas cada uma, que podem ser prorrogadas por mais uma hora. Nesta disputatio escolástica, os advogados e os promotores defendem "teses" opostas, que não podem encontrar-se jamais, sob pena de declarar-se "inepta" a defesa. Quer dizer, mesmo quando acusação e defesa concordam com a culpa ou com a inocência do acusado, têm que acusá-lo e defendê-lo em público, apresentando suas teses em oposição "contraditória". Como não há, também, consenso prévio sobre quais são os fatos, sobre o que foi e o que não foi devidamente provado distintamente do que ocorre no trial by jury - a verdade, assim, não se apresenta como o resultado de um processo de construção a partir de um consenso sobre os fatos, como no modelo adversarial, mas aparecerá como o resultado de um duelo, em que vencerá o mais forte, tal como estabelecia a antiga tradição do sistema de "provas legais", vigente no Ocidente até o Antigo Regime (Foucault, 1999).

Os advogados não costumam ater-se aos autos, e não há registros escritos de suas falas, diferentemente do procedimento dos EUA, onde a fala é registrada. Deste modo, os advogados podem mentir, pois estão sustentando a versão de um acusado que tem direito de continuar a mentir em causa própria durante seu novo interrogatório. Assim, o conteúdo dos autos, resumido em relatório e lido pelo juiz, é, neste momento, manipulado livremente tanto pela acusação quanto pela defesa, dando lugar a controvérsias ferozes sobre a existência, ou não, de provas, fatos e indícios.

Sem que tenham sido esclarecidos oficialmente sobre quais os fatos efetivamente provados do processo, nem sobre suas implicações legais, como é obrigatório nos EUA, os jurados recolhem-se a uma sala secreta, na companhia do juiz, de um serventuário da justiça - que os acompanhou durante todo o tempo do julgamento para que não se comunicassem entre si, nem com o público -, de representantes da defesa e da acusação - o que difere da reunião secreta para discussão do processo e negociação do verdict dos doze jurados nos EUA, à qual ninguém pode assistir. No Brasil, os jurados são proibidos de discutir entre si e votam, secretamente, de acordo com sua consciência, colocando cédulas marcadas com sim ou não em uma urna, em resposta a uma série de perguntas extremamente técnicas, que incluem o exame de agravantes e de atenuantes, formuladas pelo juiz, com a anuência da acusação e da defesa (a quesitação). Em suma, esse procedimento também difere em muito da alternativa guilty/not guilty usada na arbitragem dos EUA, em que os jurados discutem entre si e votam abertamente pela decisão que expressa o consenso - muitas vezes obrigatório -, o que caracteriza um ritual de produção de verdade distinto do júri brasileiro.

\section{OS JUIZADOS ESPECIAIS CRIMINAIS}

Criados pela Lei $\mathrm{n}^{\circ}$ 9.099/95, os Juizados Especiais Criminais - Jecrim constituem-se uma instituição processual ainda em implantação no Brasil. De certa forma, os Jecrim vieram ocupar um lugar que pertencia, extra-oficialmente, à polícia judiciária, que apurava e julgava o tipo de crimes de menor potencial ofensivo - com penas de até dois anos - antes da nova lei.

Os Jecrim, embora não se definindo oficialmente como tal, pretendem introduzir uma espécie de civilização da lei penal, buscando, mediante a composição e a transação penal, saídas alternativas para as penas de prisão. Entretanto, devido a vários fatores, não sendo de menor importância aqueles ligados à tradição inquisitorial e de aplicação desigual do direito a segmentos distintos da população descritos acima, o tratamento desigual dado às partes em função de seu status social, a ausência de funcionários e de operadores especialmente sensíveis a uma atuação tão díspar daquela encontrada no sistema de justiça criminal tradicional e uma forte ambigüidade com relação à aplicação universal das garantias constitucionais, em especial no que se refere ao emprego da transação penal, estão se evidenciando como prováveis obstáculos à plena realização de seus objetivos explícitos, de desafogar os tribunais e de democratizar-lhes o acesso. Por outro lado, pesquisa empírica conduzida nos Jecrim do Estado do Rio de Janeiro demonstrou alto grau de renúncias, acatadas com conciliações bem-sucedidas pelo sistema, mas nem sempre vistas como tal pelas partes envolvidas, em especial quando estas são mulheres agredidas por seus próximos, em sua maioria do sexo masculino. Aparentemente, a conciliação opera uma desjuridificação do conflito, que permanece latente na estrutura de sociabilidade, vindo a se manifestar mais tarde, algumas vezes, com maior gravidade. $^{6}$

\section{CONSIDERAÇÕES FINAIS}

Nos últimos 20 anos, vários cientistas sociais, em especial antropólogos, têm insistido na presença de princípios paradoxais e de características ambíguas na socie- 
dade brasileira (DaMatta, 1979; Gomes; Barbosa; Drummond, 2000). Apregoa-se explicitamente a igualdade entre todos os indivíduos que compõem a sociedade, de onde decorre que os naturais desentendimentos entre eles, provocados por seus eventuais interesses divergentes, deverão ser administrados mediante negociações entre partes formalmente iguais, embora substantivamente distintas. Quer dizer, negros, brancos e índios, mulheres, homens e homossexuais, pobres, remediados e ricos, etc. serão considerados formalmente iguais no que toca à negociação de seus direitos e deveres em público. Este processo de negociação permanente é considerado capaz de emprestar à sociedade uma dinâmica democrática e um formato flexível, como em um paralelepípedo, em que os diferentes estratos sociais se encontram em permanente mobilidade e cada indivíduo/elemento tem sua própria trajetória, uma vez que a base e o topo dessa figura têm a mesma superfície. Para que a ordem pública se mantenha é necessário haver consenso sobre as regras que vão gerir a administração desses conflitos, cuja legitimidade advém de sua explicitude e universalidade, referidas necessariamente a um determinado contexto, o que lhes empresta univocidade - significado único - e literalidade: isto é, em um determinado local, as regras de convivência em público são facilmente identificáveis e valem para todos da mesma maneira. A principal estratégia de controle social é a prevenção dos conflitos pelo controle disciplinar dos indivíduos, que devem ser capazes de internalizar valores e regras apropriados à convivência social em público, embora com respeito a seus modos de vida particulares.

Esta visão republicana, democrática, igualitária e individualista da sociedade, entretanto, convive, na sociedade brasileira, com uma outra, que permanece implícita mas claramente detectável à observação - em que a sociedade, à maneira de uma pirâmide, é constituída de segmentos desiguais e complementares. Nesta última perspectiva, as diferenças que produzem inevitáveis conflitos de interesses são reduzidas à sua significação inicial, dada por uma relação fixa com contextos mais amplos do todo social. As diferenças não exprimem igualdade formal, mas desigualdade formal, própria da lógica da complementaridade, em que cada um tem o seu lugar previamente definido na estrutura social. A estratégia de controle social na forma piramidal é repressiva, visando manter o statu quo ante a qualquer preço, sob pena de desmoronar toda a estrutura social. Portanto, não se pretende que os componentes da sociedade internalizem as regras, mas a hierar- quia, pois sua aplicação não será nunca universal, mas hierarquizada, o que explica porque as regras são aplicadas desigualmente aos membros da sociedade. O sistema funciona com a aplicação particularizada de regras gerais, para isso sempre sujeitas, sucessivamente, à melhor e maior autoridade interpretativa (Kant de Lima, 2000).

Diferentemente de uma sociedade aristocrática, entretanto, onde os eixos que organizam a desigualdade política, econômica, jurídica e social encontram-se claramente demarcados, no Brasil, um Estado formalmente republicano, tais desigualdades não podem ser constitucionalmente marcadas. Embora claramente presentes na estrutura do mercado a que hoje todos estamos submetidos, não poderiam e, sobretudo, não deveriam produzir desigualdade de tratamento político-jurídico para os distintos segmentos da sociedade e para os indivíduos que os compõem, conforme princípio vigente nos Estados democráticos de Direito.

Nesse contexto, é relevante explicitar como nossa cultura jurídica justifica a desigualdade jurídica existente no sistema de justiça criminal, exemplificada pelos institutos dos fóruns especiais e privilegiados, pelos diferentes tipos de imunidade e pela prisão especial para várias categorias profissionais, inclusive para os detentores de instrução superior. Os operadores deste sistema, responsável pela garantia da liberdade de ir e vir, direito civil básico dos cidadãos de uma República, utilizam argumentação diametralmente oposta àquela presente nos textos que se referem à constituição da cidadania e do Estado de Direito no mundo capitalista: diz-se que não pode haver igualdade jurídica perante os tribunais porque existe, de fato, desigualdade econômica e social em nossa sociedade (Cogan, 1996). Assim, seria injusto tratar a todos os desiguais, igualmente ou, como disse Ruy Barbosa, ícone da república e "porta-voz" - no sentido que a esta categoria empresta Bourdieu - do campo jurídico brasileiro, insistentemente citado pelos juristas: "A regra da igualdade não consiste senão em quinhoar desigualmente aos desiguais, na medida em que se desigualam" (Barbosa, 1921). Em conseqüência, a semelhança remete à igualdade; e a especificidade, não à universalidade de tratamento, mas à sua particularidade: em suma, a diferença remete à desigualdade. Ou, nas palavras do citado autor:

"A parte da natureza varia ao infinito. Não há, no universo, duas coisas iguais. Muitas se parecem umas às outras. Mas todas entre si diversificam. Os ramos de uma só árvore, as folhas da mesma planta, os traços da polpa de um dedo humano, as gotas do mesmo fluido, os argueiros do mesmo pó, as raias do espectro de um só raio solar 
ou estelar. Tudo assim, desde os astros, no céu, até aos aljôfares do rocio na relva dos prados.

A regra da igualdade não consiste senão em quinhoar desigualmente aos desiguais, na medida em que se desigualam. Nesta desigualdade social, proporcionada à desigualdade natural, é que se acha a verdadeira lei da igualdade. O mais são desvarios da inveja, do orgulho, ou da loucura. Tratar com desigualdade a iguais, ou a desiguais com igualdade, seria desigualdade flagrante, e não igualdade real" (Barbosa, 1921, grifos meus).

A este quadro de desigualdade explícita associam-se mecanismos institucionais de "pesquisa" da verdade no processo criminal declaradamente inquisitoriais, que consistem em desconsiderar, em nome da ordem pública, todas as barreiras colocadas entre o público e o privado na sociedade contemporânea. Dá-se ao juiz a prerrogativa do chamado "livre convencimento" pela qual ele pode, inclusive, discordar de fatos considerados incontroversos pelas partes, para apropriar-se da "verdade real" (Grinover, 1999).

Assim, não é sem razão que a cidadania, enquanto noção que garante a igualdade jurídica, política e social mínima vigente nas repúblicas contemporâneas, ainda encontra dificuldades quanto a sua realização no Brasil (Carvalho, 2001), em especial no que se refere a um de seus componentes originários, os direitos civis. E isto não é um fato irrelevante nesse contexto, pois os direitos civis, segundo Carvalho (2001:9), “(...) São direitos cuja garantia se baseia na existência de uma justiça independente, eficiente, barata e acessível a todos. São eles que garantem as relações civilizadas entre as pessoas e a própria existência da sociedade civil surgida com o desenvolvimento do capitalismo. Sua pedra de toque é a liberdade individual."

Entretanto, a desigualdade de que falamos não está na lei e em práticas judiciais, sem que esteja estruturada na sociedade. Nosso Código de Processo Penal, nunca discutido ampla e democraticamente pelos cidadãos que a ele submetem sua liberdade, apenas expressa a cultura presente em nosso cotidiano, responsável pela banalização do que se convencionou chamar de práticas autoritárias categoria apropriada para definir o abuso de poder em sociedades igualitárias - e que os antropólogos preferem denominar de hierárquicas, justamente porque não se constituem em abuso, mas em cumprimento de preceitos estruturais de desigualdade (DaMatta, 1979).

Estas características emprestam ao espaço público - e à sua esfera pública, seu espaço normativo - no Brasil, certas peculiaridades (Cardoso de Oliveira, 2002), percebidas pelos operadores do sistema de justiça e segurança pública como características de nossa sociedade, que impõe a seu comportamento cotidiano a constante e inevitável negociação da aplicação particularizada de regras na esfera pública. Assim, aqueles que estão explicitamente inseridos como interlocutores no espaço público vêem como legítima a apropriação particularizada e individual das regras. Disso resulta o desprestígio da obediência literal à lei e a impossibilidade de sua aplicação coletiva e universal, igualmente a todos, como é usual na maioria das Repúblicas democráticas instituídas no Ocidente. No Brasil, a atualização de valores igualitários de modo coletivo e universal chega a ser identificada como injustiça, pois sobrepõe um sistema explicitamente igualitário (em formato de paralelepípedo) a um sistema implicitamente hierárquico (de feição piramidal), de tal modo que a convivência de ambos requer práticas e valores desiguais. A compensação do desequilíbrio decorrente das duas lógicas paradoxais é feita com o prestígio da autoridade interpretativa, sempre fluida e contextual, seja do síndico, seja do guarda de trânsito, do delegado, do promotor, do juiz, ou do governante: em suma, do inquisidor.

A conseqüência perversa desse sistema paradoxal é que, ao invés de enfatizar mecanismos de construção da ordem, enfatiza sistemas de manutenção da ordem, através de estratégias repressivas, em geral a cargo dos organismos policiais e judiciais, vistas como necessárias à administração deste paradoxo. Desse modo, as estratégias comumente usadas para a manutenção da ordem, ora são militares - fundadas nas técnicas de destruição do inimigo, a origem mais evidente da explicitação do conflito, visto como perigosamente desagregador (Silva, 2003) - ora são jurídicas, voltadas para a punição de infrações da ordem. Nenhuma delas, é claro, está adequada à construção e à manutenção de uma ordem pública democrática, que deve ser baseada na negociação pública e coletiva dos interesses divergentes de partes iguais.

Finalmente, nesse quadro, é possível compreender as agruras da internalização de uma idéia de Direitos Humanos e, mais ainda, de sua implementação como política pública. Os direitos, em nossa tradição, são sempre particularizados, e explica-se, assim, que cada categoria reivindique competitivamente os "seus" direitos humanos: das vítimas, dos policiais, dos agressores, etc., como se a "concessão" desses direitos a uns excluísse automaticamente os outros de fruí-los, como tem sido constantemente explicitado por nossos interlocutores, no campo. 


\section{NOTAS}

1. Provavelmente, o tradutor se refere ao due process of law, o chamado devido processo legal.

2. Maria Stella Amorim chamou-me a atenção para esse tipo de argumento que procura evadir ou desculpar o não cumprimento de direitos legislados. Nesse mesmo sentido, doutrinas, leis, interpretações, procedimentos incorporados à prática judiciária podem também constituir álibis que circulam em sistemas judiciários e que têm função de não permitir a explicitação de propósitos geralmente considerados negativos.

3. Para compreender quão séria é esta questão da desigualdade jurídica, acaba-se de aprovar uma nova regulamentação da "prisão especial”, denominação jurídica deste instituto. O Executivo, inicialmente motivado a extingui-la para impedir a aplicação de privilégios a um juiz que se encontrava respondendo a processo criminal, abandonou sua intenção inicial e o assunto - que é claramente inconstitucional - foi apenas regulamentado pelo Congresso, que aprovou a Lei $\mathrm{n}^{\circ}$ 10.258 , de 11/7/2001, em votação simbólica das lideranças, a qual incluiu uma nova categoria profissional - os militares em geral - no privilégio!

4. No sistema inquisitorial sempre se desconfiava muito da confissão, pois ela era sempre vista como um meio de escapar de acusações maiores, pois nesse sistema as acusações não eram conhecidas: então, procurava-se confessar infrações menores para escapar de acusações mais sérias.

5. Garapon (1997) também chama a atenção para essas diferenças na disposição espacial de tribunais dos Estados Unidos e da França.

6. Para uma discussão sobre os diferentes aspectos dos juizados especiais criminais, ver Kant de Lima et al. (2003).

\section{REFERÊNCIAS BIBLIOGRÁFICAS}

BARBOSA, R. Oração aos Moços. Faculdade de Direito de São Paulo. Obras Completas de Ruy Barbosa. Rio de Janeiro: Casa de Rui Barbosa, 1921. v.48, t.2.

BOURDIEU, P. A economia das trocas simbólicas. São Paulo: Perspectiva, 1974.

CARDOSO DE OLIVEIRA, L.R. Direito Legal e Insulto Moral. Rio de Janeiro: Relume Dumará, 2002.

CARVALHO, J.M. de. Cidadania no Brasil: o longo caminho. Rio de Janeiro: Civilização Brasileira, 2001.

COGAN, A. Prisão Especial. São Paulo: Saraiva, 1996 [s.d.].

DAMATTA, R. Você sabe com quem está falando? In: Carnavais, Malandros e Heróis. Rio de Janeiro: Zahar, 1979.
FAORO, R. Os donos do poder. Rio de Janeiro: Globo, 1958.

FOUCAULT, M. A verdade e as formas juridicas. Rio de Janeiro: Nau Editora, 1999.

GARAPON, A. Bien Juger. Essai sur le rituel judiciaire. Paris: Odile Jacob, 1997.

GRINOVER, A.P. A iniciativa instrutória do juiz no Processo Penal Acusatório. Revista Brasileira de Ciências Criminais. São Paulo, IBCCRIM, ano 7, n.27, p.71-79, jul./set. 1999.

GOMES, L.G.; BARBOSA, L.; DRUMMOND, J.A. O Brasil não é para principiantes. Rio de Janeiro: Editora da Fundação Getúlio Vargas, 2000.

KANT DE LIMA, R. Carnavais, Malandros e Heróis: o dilema brasileiro do espaço público. In: GOMES, L.G.; BARBOSA, L.; DRUMMOND, J.A. O Brasil não é para principiantes. Rio de Janeiro: Editora da Fundação Getúlio Vargas, 2000. p.105-124.

A polícia da cidade do Rio de Janeiro: seus dilemas e paradoxos. Rio de Janeiro: Editora Forense, 1995.

Cultura Jurídica e Práticas Policiais: a tradição inquisitorial. Revista Brasileira de Ciências Sociais, v.10, n.4, p.65-84, jun. 1989.

KANT DE LIMA, R.; AMORIM, M.S.; BURGOS, M.B. Juizados Especiais Criminais, Sistema Judicial e Sociedade no Brasil: ensaios interdisciplinares. Niterói: Intertexto, 2003.

L'administration de la violence quotidienne au Brésil: l'expérience des tribunaux criminels spécialisés. Nanterre. L'Harmattan, Droit et Cultures, $\mathrm{n}^{\circ}$ Hors de 'serie, n.3, p.199-228, 2001. (Numéro hors de serie).

MALATESTA, N.F. dei M. A lógica das provas em matéria criminal. Rio de Janeiro: Livraria Cruz Coutinho, 1911. 2v.

MARSHALL, T.H. Classe, cidadania e status. Rio de Janeiro: Zahar, 1967.

MENDES DE ALMEIDA JÚNIOR, J. O processo criminal brasileiro. 3. ed. aum. Rio de Janeiro: Typographia Baptista de Souza, 1920. $2 \mathrm{v}$

NEVES, M. A constitucionalização simbólica. São Paulo: Acadêmica, 1994.

SILVA, J. da. Segurança pública e polícia: criminologia crítica e aplicada. 3. ed. Rio de Janeiro: Forense, 2003. 638p.

SILVA JARDIM, A. Direito Processual Penal. 10. ed. Rio de Janeiro: Forense, 2001.

WEBER, M. Sociologia da Dominação. In: Economia e Sociedade. Brasília: Editora da Universidade de Brasília, 1999. cap. IX, v.2.

Roberto Kant de Lima: Professor da UFF, Pesquisador de produtividade do CNPq e da Faperj, Presidente da Comissão de Direitos Humanos da Associação Brasileira de Antropologia. 